7 Sue-Ling HM, Johnston D, McMahon MJ, Philips PR, Davies JA. Pre-operative identification of patients at high risk of deep venous thrombosis after elective major abdominal surgery. Lancet 1986;i:1173-6.

8 Jorgensen JO, Hanel KC, Morgan AM, Hunt JM. The incidence of deep vein thrombosis in patients with superficial thrombophlebitis of the lower limbs. 7 Vasc Surg 1993;18:70-3.

Skillman J, Kent KC, Porter DH, Kim D. Simultaneous occurrence of superficial and deep thrombophlebitis in the lower extremity. F Vasc Surg 1990;11:818-24.

10 Lutter KS, Kerr TM, Roedersheimer LR, Lohr JM, Sampson MG, Cranley JJ. Superficial thrombophlebitis diagnosed by duplex scanning. Surgery 1991;110:42-6.

11 Edwards EA. Thrombophlebitis of varicose veins. Surg Gynecol Obstet 1938;66:236-45.
12 Bergqvist $D$, Jarozewski $H$. Deep vein thrombosis in patients with superficial thrombophlebitis of the leg. $B M f$ 1986;292:658-9.

13 Galloway IMD, Karmody AM, Mavor GE. Thrombophlebitis of the long saphenous vein complicated by pulmonary embolism. Brf Surg 1969;56:360-1.

14 Plate G, Eklof B, Jensen R, Ohlin P. Deep venous thrombosis, pulmonary embolism and acute surgery in thrombophlebitis of the long saphenous vein. Acta Chir Scand 1985;151:241-4.

15 Clagett GP, Reisch JS. Prevention of venous thromboembolism in general surgical patients: results of meta-analysis. Ann Surg 1988;208:227-40.

16 Campbell WB, Ridler BMF. Varicose vein surgery and deep vein thrombosis. Br f Surg 1995;82:1494-7.

\title{
Children and sport
}

\section{Encouraging a healthy attitude to exercise should start in primary school}

Links between exercise and health are well established, ${ }^{1}$ yet levels of activity among adults are at best moderate and in many cases low. ${ }^{2-4}$ Concerns about the decline in provision of physical activity for children at school have been raised at various times during the past decade. ${ }^{56}$ Against this background the British government's new policy statement on sport, "Raising the Game," aims to help schools to re-establish sport as "one of the great pillars of education," to achieve "the wider social and health benefits of sport," and to assist children to make "informed decisions about adopting healthy and active lifestyles." Although this comes at a time when schools have weathered a great deal of change, much of which has affected the teaching of sport, ${ }^{5}$ cynics might still observe that there is a lot of ground to be made up before all pupils play sport in the sunlit uplands described in the report. The main thrust of the publication is about raising standards and levels of participation, but medical interest will focus on its statements about the contribution of sport to health.

British children now take part in less physical activity at school than almost all of their European counterparts. ${ }^{8}$ In $1987,38 \%$ of 14 year olds at state schools did less than two hours' physical education a week, and by 1990 the figure was $71 \%$ (although recently there has been a small improvement). ${ }^{9}$ In 1994, a survey of 4400 children aged 6 to 16 revealed that just under half of them spent two or more hours per week in physical education lessons. ${ }^{10}$ Even among primary school children, sustained periods of regular activity lasting for 20 minutes, which raise the heart rate above recommended thresholds, are not as common as they might be. ${ }^{11}$ Poorly maintained playing fields and shortages of qualified teachers of physical education at primary level also contribute to reduced activity levels in this age group. ${ }^{12}$ Although children remain the fittest section of the population, few experience regular levels of activity at school or at home sufficiently energetic to stress their heart and lungs appropriately. ${ }^{13-15}$

Sedentary children become sedentary adults, ${ }^{816}$ and activity declines in children as they grow up; boys and girls of 17 and 18 can be as much as $50 \%$ less active than those in early years of secondary schooling. ${ }^{17}$ Physical activity at school is an important determinant of children's exercise behaviour. Outside of school, less than half of children exercise more than three times a week, although the majority do so at least once. ${ }^{17}$ Interventions to change children's preferred activity levels need to start early, probably in primary schools, ${ }^{14}$ or better still at home. ${ }^{18}$ The problem is in getting the recipe right-get it wrong and you can put children off for life. ${ }^{17-20}$

Has the British government got it right with its strong emphasis on competitive sport and team games? The policy statement proposes a minimum of two hours of sport and physical education a week for all children aged up to 16 . Within this, more time is to be given to team games. As a result of the report, schools may offer extra sport to those children who want more, but the particular need to encourage more activity in sedentary 16-18 year olds still at school is largely ignored. And what about the actual activities available at school? Surely, in addition to offering experience of the fun of playing as a member of a team, we should also be developing an understanding of how to acquire and maintain a reasonable level of fitness, cultivating in children skills sufficient to enable them to enjoy a range of indoor, outdoor, and dance activities, and most of all generating an enthusiasm sufficient for young people to want to continue some form of physical activity when schooling ends.

Giving more of the very modest two hours a week of physical education to team games leaves less time for the other areas, even if certain schools do manage to offer some of these activities as options outside the school day. The low training effect of lessons and lack of qualified teachers in some schools $^{12}$ will be partly addressed by following the report's recommendation to improve professional and inservice training of physical education teachers and by encouraging non-specialist teachers to gain coaching awards. None of this is new-even the proposed discretionary awards to teachers for out of hours work have been in use for some time-but perhaps making these plans more explicit will in the longer term help to raise standards in some lessons.

Doctors of many specialties have an interest in this paper. Today's schoolchildren are tomorrow's middle aged local populations. Purchasers of health care expend efforts promoting the benefits of exercise while providers use scarce resources treating the results of inactivity. Encouraging middle aged people to take more exercise has its place, but social and educational policies designed to develop in children, from the beginning, positive attitudes to exercise are more likely to be effective. The policy statement is a start.

HELEN TRIPPE

West Surrey Health Commission,

Consultant in public health medicine

The Ridgewood Centre,

Camberley,

Surrey GU16 5QE

1 Fentem PH. Benefits of exercise: the evidence. Manchester: Manchester University Press, 1990.

2 Allied Dunbar National Fitness Survey. A report on activity patterns and fitness levels. London: Sports Council and Health Education Authority, 1992.

3 Carey S, Maidment A, Bennett N, Flatley J. Health survey for England. 1992. London: HMSO, 1993.

4 Prentice AM, Jebb SA. Obesity in Britain: gluttony or sloth? BMF 1995;311:437-9.

5 Statement made by the Conference of Medical Royal Colleges. In: Central Council of Physical Recreation. A charter for school sport: the importance of school sport in the Health of the Nation. London: CCPR, 1994.

6 Education, Science, and Arts Committee, House of Commons. Sport in schools. Minutes of evidence: 16 fanuary 1991. London: HMSO, 1991.

Department of National Heritage. Sport: raising the game. London: Department of National Heritage, 1995.

8 Armstrong $\mathrm{N}$, McManus A. Children's fitness and physical activity: a challenge for physical education. British fournal of Physical Education 1994;25(1):20-6.

9 Central Council of Physical Recreation. An enquiry into the provision of physical education in secondary schools by the Secondary Heads Association. London: Secondary Heads Association and the CCPR, schools by

10 Mason V. Young people and sport in England, 1994. London: The Sports Council, 1995. 
11 Cale L, Almond L. Physical activity levels of young children: a review of the evidence. Health Education f 1992;51:94-9.

2 National Association of Headteachers. National survey of physical education in primary schools. London: Central Council for Physical Recreation and the Association of Headteachers, 1992.

13 Her Majesty's Inspectors. A survey of physical education in key stages 1, 2 and 3, 1993-4. Wales: Office of Her Majesty's Chief Inspector of Schools in Wales, 1995.

4 Armstrong N, Balding J, Gentle P, Kirby B. Patterns of physical activity among 11 to 16 year old children. $B M 7$ 1990;301:203-5.

15 Armstromg N, McManus A, Welsman J. Children's aerobic fitness. British fournal of Physical Education 1994;25(2):9-11.
16 Kelder SK, Perry CL, Klepp KI, Lytle LL. Longitudinal tracking of adolescent smoking, physical activity and food choice behaviours. Am $\mathcal{F}$ Public Health 1994;84:1121-6.

17 Riddoch C, Savage JM, Murphy N, Cran GW, Boreham C. Long term implications of fitness and physical activity patterns. Arch Dis Child 1991;66:1426-33.

18 Gentle P, Caves R, Armstrong N, Balding J, Kirby B. High and low exercisers among 14 and 15 year old children. F Public Health Med 1994;16:186-94.

19 PE in the National Curriculum. Draft Revised Order (SCAA). April 1994. British fournal of Physical Education 1994;25(2):5-6.

20 Harris J. PE in the National Curriculum: is there enough time to be effective? Br $\mathcal{f}$ Phys Educ 1994;25(3):34-8.

\section{Shackling prisoners in hospital}

\section{Contravenes international law}

The shackling of women in labour in British hospitals has aroused almost universal condemnation. Last week the home secretary clarified the use of restraints on all prisoners attending hospitals. Pregnant women will no longer wear restraints within hospitals, although those considered to be high security risks will still wear them for antenatal visits and at least one of the accompanying prison staff will be a woman. But for other prisoners attending hospitals restraints will continue to be applied "unless there is a medical objection."

Maternity service organisations have already condemned the home secretary's response, and have extended their objections to the shackling of all woman prisoners, arguing that the practice is illegal under national and international law. The European Convention for the Protection of Human Rights says that no one should be subjected to degrading punishment, and the United Nations standard minimum rules for the treatment of prisoners state that chains shall not be used as restraints. ${ }^{23}$ Although shackling may seem more abhorrent in women than it does in men, in both sexes it is an abuse of human rights. Prison welfare groups have evidence of prisoners who have refused to go to funerals, child care hearings, and visits to elderly relatives because they are humiliated by being forced to wear restraints. Not all European countries chain their prisoners. In the Netherlands, chains are never used and only prisoners who have been assessed as being exceptionally dangerous are handcuffed.

Until April 1995 restraints were not usually used on women prisoners in Britain, according to the Howard League for human reform of the penal system although they were more routine for men. The policy changed after six male prisoners escaped from the special security unit at Whitemoor prison and a subsequent report criticised the level of supervision. ${ }^{4}$ In the security hype that followed a blanket policy was extended to all prisoners in secure institutions.

An amendment to the security manual issued to prisons by the Home Office states that "a closeting chain should always be used for women under escort from secure prisons." In case prison governors feel that this policy is excessive they are reminded that "the rate of escapes by female prisoners is proportionately much higher at present than that of male prisoners." Since 1990 a total of 70 women have escaped from escort -20 of them from hospitals. ${ }^{5}$ About half of all women in prison are mothers and most "escapes" involve women going home at times of family crises. In 1993, out of about 3000 women sentenced to prison in Britain, only $250(8 \%)$ had committed crimes of violence. ${ }^{6}$ Out of about 53000 men sentenced to prison in 1993, about $6500(12 \%)$ had committed violent crimes. A policy to restrain all prisoners when outside their secure institutions is not supported by the risks.

The blanket policy was never discussed with the hospitals that served the prisons. Faced with patients in chains, doctors and other hospital staff may feel unclear about their responsi- bilities. Although the prison security manual has always given doctors the right to request the removal of restraints "at the point when treatment begins," medical staff do not always know this. Some doctors have been told by prison staff that if restraints are removed it will be the doctor's responsibility if the patients escape or harm anyone. Although never legally tested, this seems highly unlikely. It is up to the prison service to maintain security and up to doctors to provide decent and humane health care. Even so, doctors may not always feel that they can make a stand.

But they should do so. Arguments about the adverse medical consequences of shackling (for example, that it will damage bonding between mother and child) are largely irrelevant. Doctors can object to seeing patients in shackles on the grounds that it is a degrading experience for both parties. Guidance on good practice from Britain's General Medical Council says that doctors must respect patients' privacy and dignity. It is not dignified for a patient to be shackled to a bed, or to be chained to a prison officer during a physical examination or treatment. Such physical restraints also ruin the trust and confidentiality between doctor and patient.

The BMA is working on guidelines for doctors on these issues. Bearing in mind that a small proportion of prisoners (men more than women) will be potentially dangerous or likely to escape, the problem of delivering health care while protecting health workers and the public cannot be totally disregarded. The level of restraint, if any, should be decided on assessment of an individual's risk and should be agreed by the prison governor and either the hospital management or a clinician who already knows the patient. Chains, because they are illegal under international law, should never be acceptable forms of restraint. Usually security can be provided by a warder of the same sex outside the consulting or treatment room with another in the grounds immediately outside. Rarely a warder may be needed for the safety of health staff behind a screen within the treatment room. It would be naive to argue that a prisoner should never be examined while wearing a restraint, but the occasions when this is necessary are exceptional. But most patients from prisons present no threat and should be treated accordingly.

LUISA DILLNER Assistant editor

BMf,

London WC1H 9JR

1 Home Secretary's statement: prisoners in hospital. House of Commons Official Report (Hansard) 1996 January 18;269:cols 893-902. (No 31.)

2 Council of Europe. The European convention on human rights. Brussels: Council of Europe, 1953.

3 United Nations Department of Economic and Social Affairs. Standard minimum rules for the treatment of prisoners and related recommendations. New York: United Nations, 1977.

4 Home Office. Report of the enquiry into the escape of six prisoners from the special security unit at Whitemoor Prison, Cambridgeshire, on Friday 9th September 1994. London: HMSO, 1994. (Cm 2741; by Sir John Woodcock.)

5 Holloway Prison. House of Commons Official Report (Hansard). 1996 January 9;269:cols 19-25. (No 25.)

6 Home Office. Prison statistics. England and Wales 1993. London: HMSO, 1994. (Cm 2898.) 